\title{
Recombinant Sheep Pox Virus Proteins Elicit Neutralizing Antibodies
}

\author{
Olga V. Chervyakova ${ }^{1}$, Valentin L. Zaitsev ${ }^{1}$, Bulat K. Iskakov ${ }^{2}$, Elmira T. Tailakova ${ }^{1}$, \\ Vitaliy M. Strochkov ${ }^{1}$, Kulyaisan T. Sultankulova ${ }^{1}$, Nurlan T. Sandybayev ${ }^{1}$, \\ Gulshan E. Stanbekova ${ }^{2}$, Daniyar K. Beisenov ${ }^{2}$, Yergali O. Abduraimov ${ }^{1}$, \\ Muratbay Mambetaliyev ${ }^{1}$, Abylay R. Sansyzbay ${ }^{1}$, Natalia Y. Kovalskaya ${ }^{3}$, \\ Lev. G. Nemchinov ${ }^{3}$ and Rosemarie W. Hammond ${ }^{3, *}$ \\ 1 Research Institute for Biological Safety Problems, RK ME\&S - Science Committee, Gvardeiskiy 080409, \\ Kazakhstan; ovch@mail.ru (O.V.C.); biosafety@biosafety.kz (V.L.Z.); tailakova_86@mail.ru (E.T.T.); \\ vstrochkov@biosafety.kz (V.M.S.); sultankul70@mail.ru (K.T.S.); nurlan.s@mail.ru (N.T.S.); \\ yergali.a@gmail.com (Y.O.A.); murat@biosafety.kz (M.M.); sansyzbai-ar@biosafety.kz (A.R.S.) \\ 2 M. A. Aitkhozhin's Institute of Molecular Biology and Biochemistry, RK ME\&S - Science Committee, \\ Almaty 050012, Kazakhstan; bulat.isakakov@mail.ru (B.K.I.); gulshanst@yahoo.com (G.E.S.); \\ daniyar.b@mail.ru (D.K.B.) \\ 3 United States Department of Agriculture, Agricultural Research Service, Molecular Plant Pathology \\ Laboratory, Beltsville, MD 20705, USA; natalia.kovalksaya@ars.usda.gov (N.Y.K); \\ lev.nemchinov@ars.usda.gov (L.G.N.) \\ * Correspondence: rose.hammond@ars.usda.gov; Tel.: +1-301-504-5203; Fax: +1-301-504-5449
}

Academic Editor: Curt Hagedorn

Received: 9 April 2016; Accepted: 30 May 2016; Published: 7 June 2016

\begin{abstract}
The aim of this work was to evaluate the immunogenicity and neutralizing activity of sheep pox virus (SPPV; genus Capripoxvirus, family Poxviridae) structural proteins as candidate subunit vaccines to control sheep pox disease. SPPV structural proteins were identified by sequence homology with proteins of vaccinia virus (VACV) strain Copenhagen. Four SPPV proteins (SPPV-ORF 060, SPPV-ORF 095, SPPV-ORF 117, and SPPV-ORF 122), orthologs of immunodominant L1, A4, A27, and A33 VACV proteins, respectively, were produced in Escherichia coli. Western blot analysis revealed the antigenic and immunogenic properties of SPPV-060, SPPV-095, SPPV-117 and SPPV-122 proteins when injected with adjuvant into experimental rabbits. Virus-neutralizing activity against SPPV in lamb kidney cell culture was detected for polyclonal antisera raised to SPPV-060, SPPV-117, and SPPV-122 proteins. To our knowledge, this is the first report demonstrating the virus-neutralizing activities of antisera raised to SPPV-060, SPPV-117, and SPPV-122 proteins.
\end{abstract}

Keywords: sheep pox virus; vaccinia virus; recombinant protein; prokaryotic expression; neutralizing antibodies; immunogenicity

\section{Introduction}

Sheep pox is a highly contagious viral disease of small ruminants that is endemic in the Near East and Central Asia, India, China, and Central and Northern Africa. The disease causes significant economic losses by reduced hide and wool quality, the prevention of the importation of new breeds of sheep into endemic regions, and other production losses in animal husbandry worldwide [1-4]. The agent of sheep pox disease is sheep pox virus (SPPV), the type species of the Capripoxvirus genus, subfamily Chordopoxvirinae, family Poxviridae. In addition to SPPV, the capripoxviruses include goatpox virus (GTPV) and lumpy skin disease virus, all of which cause pox skin lesions, are of great economic importance, and are potentially emerging disease threats [5]. To control the spread of sheep pox infection, attenuated virus vaccines are widely used in the Republic of Kazakhstan and other Former 
Soviet Union countries [6-8]. In spite of the high protection afforded by live vaccines, the possible presence of residual virulence in the latter restricts their use in disease-free areas and has led to the exploration of new approaches in vaccine development involving recombinant DNA technology [9-17].

SPPV is a large ( $>200 \mathrm{~nm}$ ), enveloped virus containing a linear double-stranded, non-fragmented DNA genome of $\sim 150 \mathrm{~kb}$ encoding at least 147 putative genes [18]. The two major infectious forms of poxviruses are the intracellular mature virion (IMV) and extracellular enveloped virion (EEV). IMVs are assembled in the cytoplasm and are composed of a core particle containing the genome and numerous enveloped enzymes. At least 11 proteins are included in the envelope of IMVs [19-27]. As IMVs accumulate, they may be freed from the cell by apoptosis or alternatively can be wrapped in additional trans-Golgi-derived membranes and released from infected cells as EEV. The lipoprotein membrane of EEV contains several unique glycosylated and non-glycosylated proteins involved in virus entry [28-34].

The complex structure and the presence of a large number of proteins in virions presents challenges to the identification of immunomodulatory proteins of pox viruses. At least 12 immunogenic proteins have been detected in SPPV [35-37]. Immunogenicity of soluble antigens was confirmed experimentally in a study where blood serum obtained after immunization of animals with soluble antigens of SPPV neutralized virus infectivity in cell culture and protected experimental animals against infection [38]. Moreover, several antigenic proteins, and their corresponding genes, have been identified and used in antibody detection of SPPV in blood sera of sheep, goats, and cattle by enzyme-linked immunosorbent assay (ELISA) [39-42].

To date there is lack of data regarding the immunological properties of individual SPPV proteins and the neutralizing activity of antibodies raised to these proteins. In our study, we cloned the genes encoding the structural proteins SPPV-060 and SPPV-117 (IMV envelope components), SPPV-122 (EEV envelope component), and SPPV-095 (found in the core of virion), produced the protein in a prokaryotic expression system, and evaluated their antigenicity and immunogenicity, along with virus neutralizing activity of antibodies raised to these proteins in cell culture.

\section{Materials and Methods}

\subsection{Viruses}

The SPPV strain "NISKhI" was kindly provided by the Microbial Collection of the Research Institute for Biological Safety Problems RK ME\&S - Science Committee, Gvardeiskiy 080409, Kazakhstan. For SPPV cultivation, a primary lamb kidney cell line maintained by the Laboratory of Cellular Biotechnology of the Research Institute for Biological Safety Problems RK ME\&S - Science Committee was used.

\subsection{Cloning of SPPV Genes}

Genes SPPV-060 (GenBank ID: NP_659632), SPPV-095 (GenBank ID: NP_659667), SPPV-117 (GenBank ID: NP_659689), and SPPV-122 (GenBank ID: NP_659694) were PCR-amplified from viral DNA, extracted from SPPV virions with Trizol (Invitrogen, Carlsbad, CA, USA), using the primer pairs described in Table 1 (restriction sites are underlined, start codon is indicated in italics). The amplified products were digested with respective enzymes (Table 1). Restriction fragments were cloned into the plasmid vectors pET23c and pET26b (containing a $\mathrm{HIS}_{6}$-tag on the C-terminus), and giving rise to $\mathrm{pET} 23 \mathrm{c} / S P P V-060, \mathrm{pET} 26 \mathrm{~b} / S P P V-095, \mathrm{pET} 26 \mathrm{~b} / S P P V-117$ and $\mathrm{pET} 26 \mathrm{~b} / S P P V-122$.

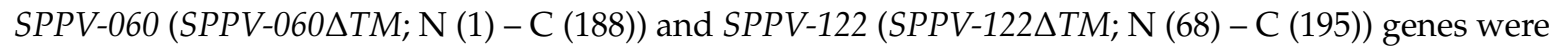
constructed to express only the extravirion domains of their encoded proteins in order to increase protein expression. The transmembrane domains were identified using the software TMHMM Server (Version 2.0) [43]. Comparative analysis of amino acid sequences of the cloned proteins and their orthologs was performed using BLAST software [44]. pET vectors were obtained from EMD Biosciences Inc. (Gibbstown, NJ, USA). 
Table 1. Oligonucleotide primers utilized in this study.

\begin{tabular}{|c|c|c|c|}
\hline Primer Name & $5^{\prime} \rightarrow 3^{\prime}$ Sequence ${ }^{a}$ & Gene Amplified & Restriction Site \\
\hline SPPV117-REV & gcatctcgagtcactttagtgttgtaattcttcctgttt & \multirow{2}{*}{ SPPV117 (NP_659689) } & XhoI \\
\hline SPPV117-DIR & gcatcatatggacagagagcgttatcaatctttccaggcga & & NdeI \\
\hline SPPV095-DIR & cccatatggacttcatgaaaaaaatatac & \multirow{2}{*}{ SPPV095 (NP_659667) } & NdeI \\
\hline SPPV095-REV & $\overline{\text { gcggccgctttgctgttattatcatcc }}$ & & NotI \\
\hline SPPV122-DIR & cccatatgcatcatcatcatcatcataataatacatgtgaattaaatc & \multirow{2}{*}{ SPPV122 $\Delta \mathrm{TM}$ (NP_659694) } & XhoI \\
\hline SPPV122-REV & ccctcgagttattaaaagttcatcatgaaaaaaagatcttacacagtaata & & NdeI \\
\hline SPPV060-DIR & attcatatggagcagccgctagtatacaaac & \multirow{2}{*}{ SPPV060 $\Delta \mathrm{TM}\left(\mathrm{NP} \_659632\right)$} & SacI \\
\hline SPPV060-REV & ctgcgagctctatataaaattgatatccgtatc & & NdeI \\
\hline
\end{tabular}

${ }^{a}$ Restriction sites are underlined; ATG start codon is indicated in italics.

Amplification reactions were performed in $50 \mu \mathrm{L}$ containing $5 \mu \mathrm{L} 10 \times$ PCR buffer (Qiagen, Valencia, CA, USA), $1 \mu \mathrm{L} 10 \mathrm{mM}$ dNTPs (NEB, Ipswich, MA, USA), $0.1 \mu \mathrm{L}$ template DNA (100 $\mathrm{ng} / \mu \mathrm{L}), 1 \mu \mathrm{L}$ of each primer $(20 \mathrm{pmol} / \mu \mathrm{L})$, and $0.25 \mu \mathrm{L}$ Taq DNA polymerase (1.25 Units, Qiagen). The amplification conditions for $S P P V-122$ were $94{ }^{\circ} \mathrm{C} 5 \mathrm{~min}$, followed by 30 cycles of $94{ }^{\circ} \mathrm{C} 1 \mathrm{~min}$, $45^{\circ} \mathrm{C} 1 \mathrm{~min}, 72{ }^{\circ} \mathrm{C} 1 \mathrm{~min}$, and a final extension at $72{ }^{\circ} \mathrm{C} 7 \mathrm{~min}$. The annealing temperature for amplification reactions of $S P P V-060, S P P V-095$, and $S P P V-117$ was $50^{\circ} \mathrm{C}$. All plasmids were sequenced to verify the integrity of the inserts.

\subsection{Gene Expression, Protein Extraction, Purification, and Raising Specific Antibodies}

Plasmids pET23c/SPPV-060, pET26b/SPPV-095, pET26b/SPPV-117, and pET26b/SPPV-122 were transformed into Escherichia coli strain BL21 (DE3) (Stratagene, La Jolla, CA, USA) or strain T7 (NEB, Ipswich, MA, USA) according to the manufacturer's instructions. Bacterial cells were grown in $50 \mathrm{~mL}$ LB-kan (Luria-Bertani broth, containing $50 \mu \mathrm{g} / \mathrm{mL}$ of kanamycin) or LB-amp (LB broth containing $50 \mu \mathrm{g} / \mathrm{mL}$ of ampicillin) at $37^{\circ} \mathrm{C}$ to a cell density of OD600 $=0.6-1.0$. Gene expression was induced by addition of IPTG to final concentration $1 \mathrm{mM}$ to the bacterial suspension with subsequent incubation for $2 \mathrm{~h}$ at $37^{\circ} \mathrm{C}$. The cells were harvested by centrifugation at $5000 \times g$ for $15 \mathrm{~min}$ and the bacterial pellet was stored at $-70{ }^{\circ} \mathrm{C}$ until protein extraction.

To prepare SPPV-060 and SPPV-117 protein samples for specific antibody production, the bacterial cell pellet was resuspended in $5 \mathrm{~mL}$ of $1 \times$ Laemmli sample buffer (Bio-Rad, Hercules, CA, USA) supplemented with $\beta$-mercaptoethanol $(2.5 \% \mathrm{v} / \mathrm{v})$ and boiled for $10 \mathrm{~min}$. The resulting samples were separated by electrophoresis in a Novex 10\%-20\% Tris-Glycine Gel (Novex, Carlsbad, CA, USA) and visualized by staining with Simply Blue Safe Stain (Invitrogen, Carlsbad, CA, USA). Protein bands corresponding to the recombinant SPPV proteins SPPV-060 and SPPV-117 were excised from the gel and sent to the Pacific Immunology Corp. (Ramona, CA, USA) for rabbit polyclonal antibody production. Four-fold immunization was conducted at intervals of three weeks. The first immunization was performed by administration of the protein with complete Freund's Adjuvant; proteins with incomplete Freund's Adjuvant were used for the next three injections. One week after the last immunization, the animals were bled to obtain the antiserum.

Inclusion bodies (IBs) formed in E. coli producing SPPV-095 and SPPV-122 proteins were purified using the BugBuster Master Mix Protein Extraction Reagent (Novagen, Madison, WI, USA), resuspended in the same reagent (according manufacturer's instructions) and used for rabbit polyclonal antibody production at the Research Institute for Biological Safety Problems RK ME\&S Science Committee. The animals were immunized twice at an interval of two weeks. The first injection was conducted with purified IBs, and the second injection was performed with a mixture of IBs and Montanide ISA-70 (Seppic, Puteaux, France). Three weeks after the second immunization, the animals were bled to obtain antiserum. 


\subsection{Western Blot Analysis}

For immunodetection, recombinant proteins were separated in a Novex $10 \%-20 \%$ Tris-Glycine Gel (Novex, Carlsbad, CA, USA), transferred to a nitrocellulose membrane (Invitrogen, Carlsbad, CA, USA) and probed, according to the manufacturer's instructions, with either the anti-His (C-term)-AP antibody (Invitrogen, Carlsbad, CA, USA), antigen-specific antiserum produced in rabbits, or antiserum obtained from sheep experimentally infected with SPPV using a dilution of 1:1000. After protein transfer, the nitrocellulose membrane was briefly incubated for $1 \mathrm{~h}$ at room temperature (RT) or overnight (ON) at $4{ }^{\circ} \mathrm{C}$ in blocking buffer ( $1 \times$ PBS, containing $5 \%$ non-fat dry milk). The membrane was probed with primary antigen-specific serum for two hours at RT or ON at $4{ }^{\circ} \mathrm{C}$, washed three times with PBS-Tween $20(1 \times$ PBS supplemented with $0.1 \%(v / v)$ Tween 20$)$ and incubated in alkaline phosphatase-conjugated goat anti-rabbit or anti-sheep antibody for $1-2 \mathrm{~h}$ at RT. After three washes with PBS-Tween 20, the membrane was developed by utilizing the BCIP/NBT Phosphatase Substrate System (Kirkegaard and Perry, Inc., Gaithersburg, MD, USA), according to the manufacturer's instructions.

\subsection{Virus Neutralization Studies}

A primary lamb kidney cell line was used to perform virus neutralization tests. The confluent monolayer culture was trypsinized and resuspended in complete medium. Cells were counted using a hemocytometer and $5 \times 10^{4}$ cells/well $(0.2 \mathrm{~mL} /$ well final $)$ in a 96-well tissue culture plate. Plates were incubated until the cells were confluent.

The sera under study were inactivated by heating at $60^{\circ} \mathrm{C}$ for $30 \mathrm{~min}$ and diluted two-fold starting from 1:2 to 1:64, preparing $2 \mathrm{~mL}$ of each dilution and using the supporting cell maintenance medium of primary lamb kidney cell cultures as the diluent. Each dilution of serum was added to an equal volume of SPPV in a selected dose, e.g., 100 tissue cytopathic doses (50\% tissue culture infectious dose (TCID50)). Mixtures of virus with the serum dilutions were incubated at $4{ }^{\circ} \mathrm{C}$ for $16 \mathrm{~h}$. Two hundred $\mu \mathrm{L}$ of the mixture were added to each of four wells containing the confluent monolayer cell cultures in a 96-well plate (Corning Inc., Corning, NY 14831, USA). The cell cultures were incubated for one week at $37^{\circ} \mathrm{C}$ to observe cytopathic effects (CPE). The results were read on the seventh day of incubation and were based on the presence of SPPV-induced CPE. The dilution that inhibits CPE caused by virus in $50 \%$ of infected cell cultures is considered to be the antibody titer of the serum under study. The following controls were used: virus control (virus + medium); serum control (serum + medium), and control-mock (medium).

\subsection{Light Microscopy}

96-well plates containing cell cultures with different treatments were examined using a Leitz diavert microscope with a CAMV200 digital camera and Motic Images 2000 software (Version 1.3).

\section{Results}

\subsection{Gene Expression and Purification of Recombinant Proteins}

To obtain antiserum specific to SPPV proteins for further immunological investigations, the genes encoding these proteins were amplified from the virus and inserted into pET-based expression vectors (Figure 1). Constructs containing the SPPV-060 and SPPV-122 genes were engineered to express only extravirion domains in order to enhance protein production in bacterial cells. Induction of recombinant protein expression in bacteria using IPTG resulted in the production of SPPV-060 (22 kDa; Figure 2A, lane 3), SPPV-095 (20 kDa; Figure 2C, lane 6), SPPV-117 (19 kDa; Figure 2B, lane 2), and SPPV-122 $(16 \mathrm{kDa}$; Figure $2 \mathrm{C}$, lane 2$)$ proteins. The sizes of these proteins were consistent with the predicted molecular masses. Electrophoretic analysis revealed that the SPPV-117 protein was produced in a soluble form (Figure 2B, lane 3), whereas SPPV-060 (Figure 2A, lane 3), SPPV-095 (Figure 2C, lane 8), and SPPV-122 (Figure 2C, lane 4) proteins were localized in IBs. The purified recombinant proteins were used for rabbit polyclonal antibody production (see Materials and Methods). 
pET23c/SPPV-060

\begin{tabular}{|l|l|l|l|l|l|l|l|}
\hline $\mathrm{T} 7$ & $\mathrm{rbs}$ & $\begin{array}{c}S P P V-060 \\
\Delta \mathrm{TM}\end{array}$ & His-Tag & $\mathrm{T} 7$ term & \\
\hline
\end{tabular}

pET26b/SPPV-095

\begin{tabular}{|l|l|l|l|l|l|}
\hline $\mathrm{T} 7$ & rbs & SPPV-095 & His-Tag & T7 term \\
\hline
\end{tabular}

pET26b/SPPV-117

\begin{tabular}{|l|l|l|l|l|l|l|l}
\hline $\mathrm{T} 7$ & rbs & His-Tag & SPPV-117 & T7 term & \\
\hline
\end{tabular}

pET26b/SPPV-122

\begin{tabular}{|l|l|l|l|l|l|}
\hline $\mathrm{T} 7$ & $\mathrm{rbs}$ & His-Tag & $\begin{array}{c}\text { SPPV-122 } \\
\Delta \mathrm{TM}\end{array}$ & $\mathrm{T} 7$ term \\
\hline
\end{tabular}

Figure 1. Schematic representation of pET-based expression cassettes encoding sheep pox virus (SPPV) proteins. Bacteriophage T7 promoter (T7); ribosomal binding site sequence (rbs); SPPV-060, SPPV-095, SPPV-117, SPPV-122 (SPPV gene sequences); deleted transmembrane domain $(\triangle \mathrm{TM})$; sequence coding six histidine molecules (His-Tag); T7 terminator (T7 term).
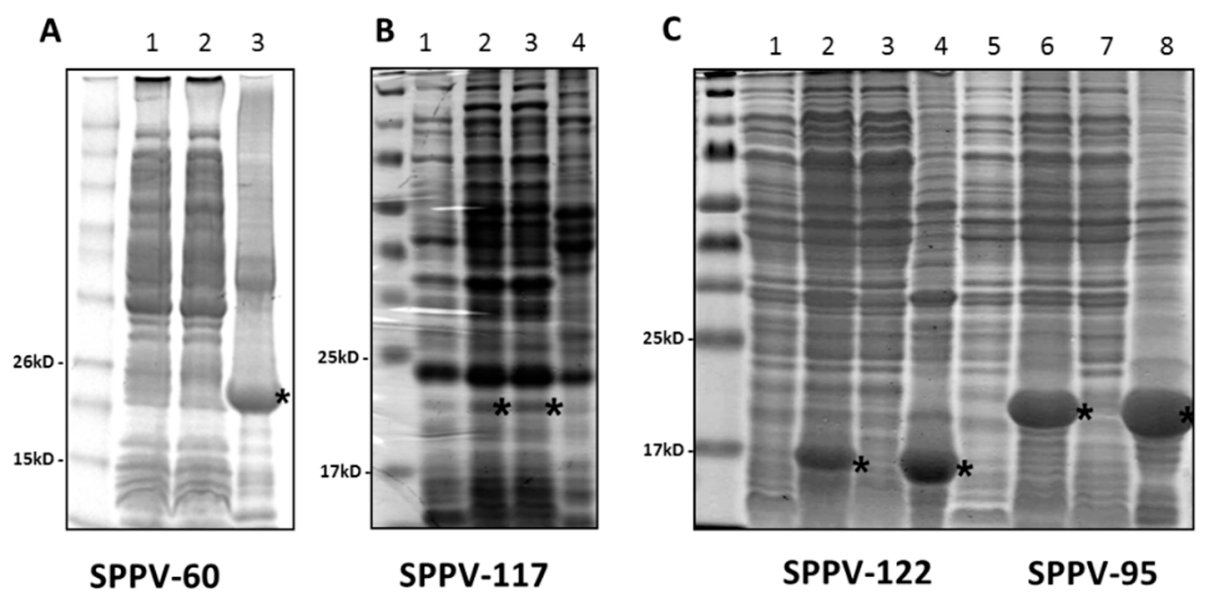

Figure 2. Denaturing 10\%-20\% polyacrylamide gel electrophoretic analysis of the protein fractions produced in E. coli transformed by pET23c/SPPV-060, pET26b/ SPPV-117, pET26b/SPPV-122 and pET26b/SPPV-095. (A) SPPV-060 protein analysis. Lane 1: $5 \mu \mathrm{L}$ of total protein fraction; Lane 2: $5 \mu \mathrm{L}$ of soluble protein fraction; Lane 3: $10 \mu \mathrm{L}$ of protein fraction after IB purification. The gel was stained with SimplyBlue SafeStain (Invitrogen, Carlsbad, CA, USA). M: BenchMark ${ }^{\mathrm{TM}}$ Pre-Stained Protein Ladder (Invitrogen, Carlsbad, CA, USA). (B) SPPV-117 protein analysis. Lane 1: $5 \mu \mathrm{L}$ of total proteins prior to IPTG induction; Lane 2: $5 \mu \mathrm{L}$ of total protein fraction; lane 3: $5 \mu \mathrm{L}$ of soluble protein fraction; lane 4: $10 \mu \mathrm{L}$ of protein fraction after IB purification. The gel was stained with Coomassie Brilliant Blue R-250. M: Spectra Multicolor Broad Range Protein Ladder (Thermo Scientific, Waltham, MA, USA). (C) SPPV-122 protein (Lanes 1-4) and SPPV-095 protein (Lanes 5-8) analysis. Lanes 1, 5: $5 \mu \mathrm{L}$ of total protein prior to IPTG induction; Lanes 2, 6: $5 \mu \mathrm{L}$ of total protein fractions; Lanes 3, 7: $5 \mu \mathrm{L}$ of soluble protein fractions; Lanes 4, 8: $10 \mu \mathrm{L}$ of protein fraction after IB purification. The gel was stained with Coomassie Brilliant Blue R-250. M: Spectra Multicolor Broad Range Protein Ladder (Thermo Scientific, Waltham, MA, USA). The recombinant SPPV proteins are indicated by small asterisks.

\subsection{Immunodetection of Recombinant Proteins}

All immunodetection assays were conducted by Western blot analysis. Recombinant protein production in E. coli was confirmed using anti-His (C-term)-AP antibody (Figure 3A). The second 
staining band in Figure 3A, lane 6 (not asterisked) may be due to target protein degradation. The antigenic properties of SPPV-060, SPPV-095, SPPV-117, and SPPV-122 proteins were detected using antisera obtained from experimentally SPPV infected sheep (Figure 3B, lanes 1-4). The immunogenicity of tested proteins was determined using antibodies raised via rabbit immunization with purified recombinant proteins (Figure 4A-D). The results of these experiments showed that antibodies in both cases reacted with the recombinant SPPV proteins.

A

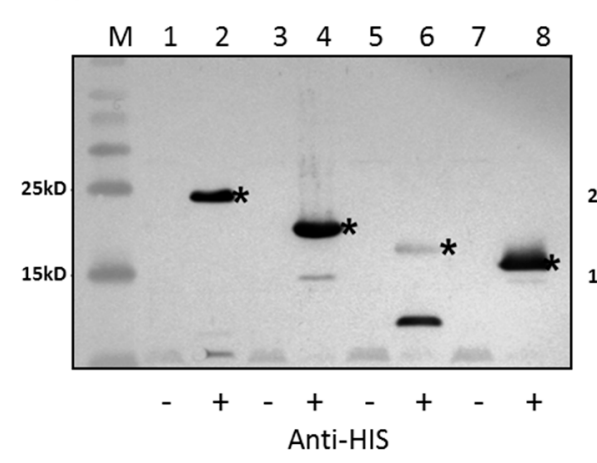

B

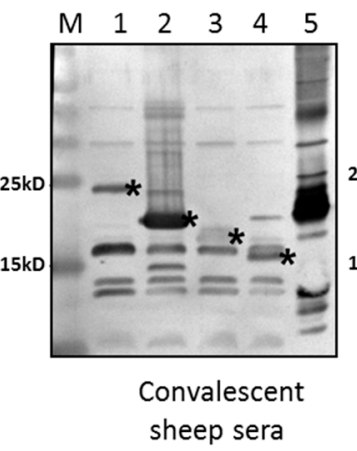

C

$\begin{array}{llllll}M & 1 & 2 & 3 & 4 & 5\end{array}$

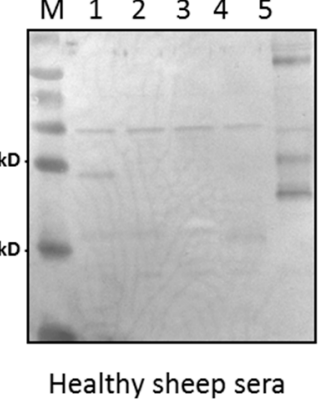

Figure 3. Western blot analysis of the SPPV recombinant proteins produced in E.coli. (A) Protein gel loaded with $5 \mu \mathrm{L}$ of total protein fractions before (Lanes 1, 3, 5, 7) and after IPTG-induction (Lanes 2, 4, 6, 8). Lanes 1, 2: SPPV-60; Lanes 3, 4: SPPV-095; Lanes 5, 6: SPPV-117; Lanes 7, 8: SPPV-122. Anti-His (C-term)-AP antibody (Invitrogen, Carlsbad, CA, USA) was used to develop the blot. (B, C) Protein gel loaded with $5 \mu \mathrm{L}$ of total protein fractions after induction of SPPV-060 (Lane 1), SPPV-095 (Lane 2), SPPV-117 (Lane 3), SPPV-122 (Lane 4), and purified sheep pox virus (Lane 5). The sera from the sheep experimentally infected with the sheep pox virus $(\mathbf{B})$ and from healthy sheep $(\mathbf{C})$ were used. M: Spectra Multicolor Broad Range Protein Ladder (Thermo Scientific, Waltham, MA, USA). The recombinant SPPV proteins are indicated by asterisks.

A $\quad$ B $\quad$ C

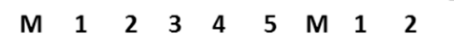

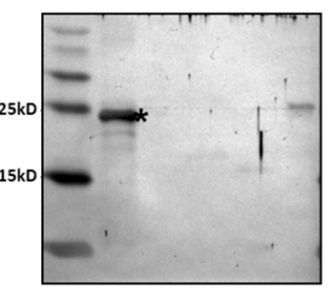

anti-SPPV-060

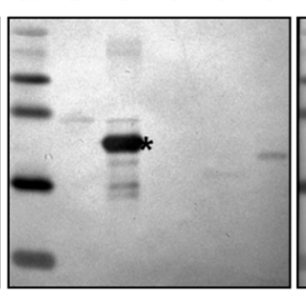

anti-SPPV-095
C

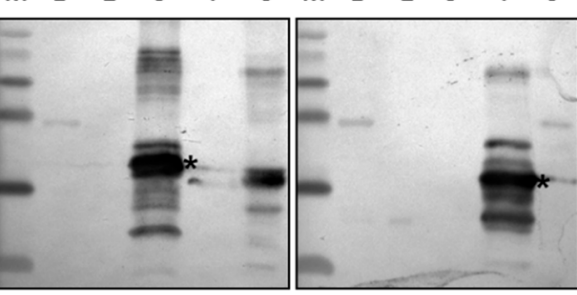

anti-SPPV-117

anti-SPPV-122
E

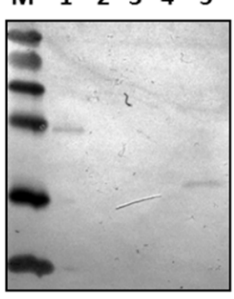

Pre-immune serum

Figure 4. Western blot analysis of the recombinant SPPV proteins produced in E.coli. Protein gels loaded with $5 \mu \mathrm{L}$ of total protein fractions after induction of SPPV-060 (lane 1), SPPV-095 (lane 2), SPPV-117 (lane 3), SPPV-122 (lane 4), and purified sheep pox virus (lane 5). The sera from the rabbits immunized with recombinant proteins SPPV-060 (A); SPPV-095 (B); SPPV-117 (C); SPPV-122 (D); and normal rabbit serum (E) were used to develop the blots. M: Spectra Multicolor Broad Range Protein Ladder (Thermo Scientific, Waltham, MA, USA).

\subsection{Neutralization Assays of Polyclonal Antibodies Raised to the Recombinant Proteins}

The virus-neutralizing activities of antiserum raised to SPPV-060, SPPV-095, SPPV-117, and SPPV-122 proteins were investigated by monitoring CPE in monolayers of primary lamb kidney cell cultures infected with a viral suspension of SPPV (a mixture of EEV and IMV) treated with different antiserum dilutions (see Materials and Methods). The first signs of CPE appearance were observed in 48-72 $\mathrm{h}$ depending on the antiserum dilution and expressed through cell rounding, the appearance 
of cavities in the monolayer, cell detachment from vial walls, vacuolization of nuclei, loss of cellular monolayer continuity, and cytoplasmic inclusion body formation in the virus-affected cells (Figure 5D). The cytopathic effect was assessed on the seventh day post incubation. The wells exhibiting CPE (Figure 5C,D) were scored as "+" and the wells with CPE (Figure 5A,B) were scored as "-". The results are shown in Table 2. The serum dilution that inhibited the virus-induced CPE in 50\% of infected cell culture was considered as the titer of virus neutralizing antibodies. Antibodies to SPPV-060, SPPV-117 and SPPV-122 proteins neutralized SPPV with a serum titer of $3.75 \log _{2}, 4.0 \log _{2}$, and $3.5 \log _{2}$, respectively, however, antiserum to SPPV-095 protein failed to neutralize SPPV in cell culture (Table 2). Visual evidence for virus neutralization using a 1:2 dilution of SPPV-117 antiserum is shown in Figure 5B where the treated cells resemble healthy, untreated cells (Figure 5A) while cells treated with a mixture of SPPV and a 1:32 dilution of SPPV-117 antiserum show signs of CPE (Figure 5C), similar to those of virus-infected cells (Figure 5D). The "pre-bleed" sera were also analyzed in the virus neutralization test. Inhibition of virus-induced CPE in cell culture was not observed (data not shown).
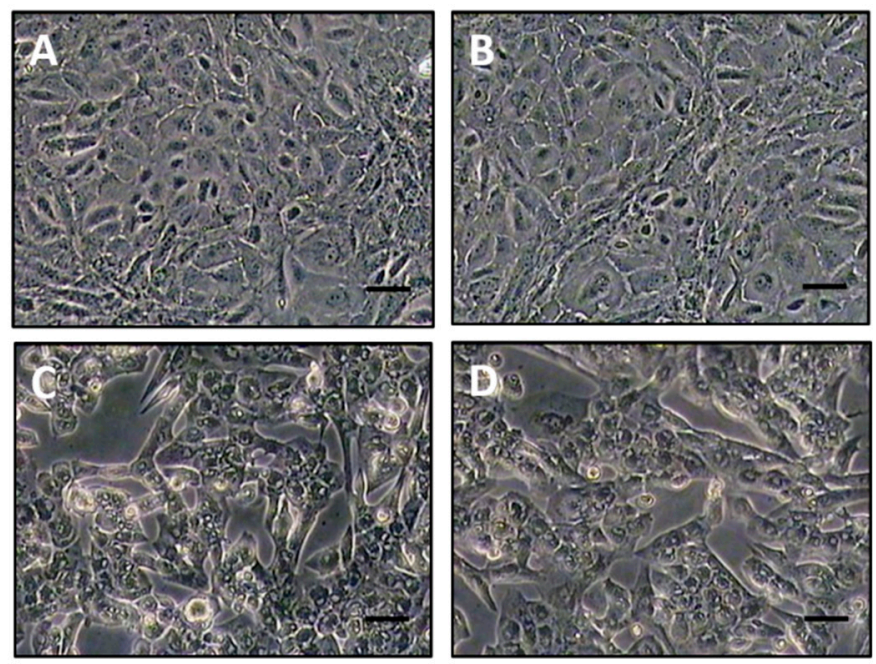

Figure 5. Monolayer of lamb kidney cell culture on the seventh day of incubation: (A) healthy cells (control-mock); (B) cells treated with a mixture of SPPV and antiserum raised to SPPV-117 protein in a dilution 1:2 (A, B; Magnification: $100 \times$ ); (C) cells treated with a mixture of SPPV with antiserum raised to SPPV-117 protein in a dilution 1:32; (D) cells infected with SPPV (virus control). (C, D; Magnification: $200 \times)$.

Table 2. Sheep pox virus (SPPV) neutralization with the specific sera to the recombinant proteins.

\begin{tabular}{|c|c|c|c|c|c|c|c|c|c|c|}
\hline \multirow[b]{2}{*}{ Components } & \multicolumn{6}{|c|}{ Serum Dilutions } & \multicolumn{3}{|c|}{ Control } & \multirow{2}{*}{$\begin{array}{c}\text { Geometric } \\
\text { Average Titer of } \\
\text { Neutralizing } \\
\text { Antibodies } \log _{2}\end{array}$} \\
\hline & $1: 2$ & 1:4 & $1: 8$ & 1:16 & $1: 32$ & 1:64 & $\begin{array}{l}\text { Virus }(100 \\
\left.\text { TCD }_{50}\right)+ \\
\text { Medium }\end{array}$ & $\begin{array}{r}\text { Serum 1:2 } \\
+ \text { Medium }\end{array}$ & medium & \\
\hline $\begin{array}{l}\text { Serum to the } \\
\text { protein SPPV060 + } \\
\text { virus }\left(100 \mathrm{TCD}_{50}\right)\end{array}$ & --- & --- & $-\cdots$ & -+++ & ++++ & ++++ & ++++ & $-\cdots$ & --- & 3.75 \\
\hline $\begin{array}{l}\text { Serum to the } \\
\text { protein SPPV095+ } \\
\text { virus }\left(100 \mathrm{TCD}_{50}\right)\end{array}$ & ++++ & ++++ & ++++ & ++++ & ++++ & ++++ & ++++ & $-\cdots$ & --- & 0.0 \\
\hline $\begin{array}{l}\text { Serum to the } \\
\text { protein SPPV117 + } \\
\text { virus }\left(100 \mathrm{TCD}_{50}\right)\end{array}$ & $\ldots$ & $\ldots$ & $-\ldots$ & --++ & ++++ & ++++ & ++++ & - - - & $-\ldots$ & 4.0 \\
\hline $\begin{array}{l}\text { Serum to the } \\
\text { protein SPPV122+ } \\
\text { virus }\left(100 \mathrm{TCD}_{50}\right)\end{array}$ & $-\ldots$ & $-\cdots$ & $-\ldots$ & ++++ & ++++ & ++++ & ++++ & $-\cdots$ & $-\ldots$ & 3.5 \\
\hline
\end{tabular}




\section{Discussion}

The choice of proteins used in this study was based on reports of the immunogenic properties of proteins of the most investigated representative of the family Poxviridae, vaccinia virus (VACV). According to the literature, some VACV proteins induce specific humoral and cellular immune responses and provide protection against subsequent orthopoxvirus infection. The most suitable candidates for subunit vaccine development are proteins encoded by A27L [45,46], D8L [47], H3L [48,49], L1R [21,50-52], B5R [53,54], A33R [55,56], and L4R and A4L [57] genes.

We investigated the antigenic and immunogenic properties of SPPV-060, SPPV-095, SPPV-117, and SPPV-122 proteins of SPPV, orthologs of VACV L1, A4, A27, and A33 proteins, respectively. To engineer the protein expression cassettes, amino acid sequence analysis of SPPV-060, SPPV-095, SPPV-117, and SPPV-122 proteins was conducted, which revealed that SPPV-060 and SPPV-122 possess putative transmembrane domains (data not shown). The presence of transmembrane domains and signal peptides in the target protein sequence can often result in either a lower level or absence of gene expression in bacterial cells [58]. In our experiments, in order to increase SPPV-060 and SPPV-122 production in E. coli, the gene sequences encoding the extravirion domains of these proteins were used to construct corresponding expression cassettes. The amplified SPPV regions encoding SPPV-060, SPPV-095, SPPV-117, and SPPV-122 proteins were cloned into the respective pET vectors (see Materials and Methods) and expressed in bacterial cells as N- or C-terminal His-tagged fusion proteins. One disadvantage of prokaryotic expression systems is the absence of post-translational modifications and, often, proper folding of proteins produced in bacterial cells [59]. However, it was shown by Berhanu et al. [60] that bacterially expressed A27L, B5R, and D8L proteins of VACV retained their antigenic and immunogenic properties. In our study, Western blot analysis revealed the reaction of bacterially-produced SPPV-060, SPPV-095, SPPV-117, and SPPV-122 proteins with antiserum from sheep experimentally infected animals with SPPV (Figure 3B, lanes 1-4) and with antiserum raised to purified recombinant proteins (Figure 4A-D). The results of these experiments confirm the antigenic and immunogenic properties of the recombinant proteins. It is interesting that sera of healthy animals revealed insignificant antibody binding to the recombinant proteins (Figure 3C, lanes 1-4). The slight immune background is probably associated with circulation of the virus among sheep as a result of using the live attenuated sheep pox vaccine in Kazakhstan.

Recombinant SPPV-122 protein, an EEV envelope component, displayed antigenic and immunogenic properties that were confirmed by Western blot analysis. Moreover, rabbit immunization with SPPV-122 led to production of antibodies possessing virus-neutralizing activity towards SPPV. Interestingly, according to the literature, antibodies to VACV A33 protein, an ortholog of SPPV-122, did not neutralize VACV in vitro [61].

SPPV-060 and SPPV-117 proteins, components of the IMV envelope, possessed antigenic and immunogenic properties as well. They induced formation of virus-neutralizing antibodies (Table 2) as do their VACV orthologs (L1 and A27, respectively). Rodriguez et al. [62] reported that monoclonal antibodies to A27 protein completely inhibited virus-cell binding. Lai et al. [63] and Demkowicz et al. [57] demonstrated that immunization of mice with VACV A27 protein resulted in the production of virus-neutralizing antibodies in a high titer and the animals were completely protected against subsequent infection with a lethal dose of the VACV strain WR. VACV L1 protein induced production of IMV-neutralizing antibodies in mice in titers sufficient for complete protection against 5 LD50 of VACV WR [64], however at a higher infecting dose (100 LD50), only 28\% of animals survived. In an independent study, it was shown that partial protection of mice against VACV infection was induced by polyclonal antiserum to L1 protein by passive immunization $[65,66]$. Moreover, L1 protein, a component of the mature virion membrane, is conserved in all sequenced poxviruses [67], so we can speculate that an L1-based vaccine developed against one poxvirus would stimulate immunity to the entire group of poxviruses [68]. The cross-neutralizing activity of antiserum-raised to soluble antigens-between Capripoxvirus members has also been demonstrated [69]. The conserved nature of 
ORF 117 (SPPV-117) between SPPV and GTPV isolates suggests that recombinant vaccine based on SPPV-117 may serve as a single vaccine for both diseases [70].

The high antigenicity of the SPPV-095 protein, found in the core of the sheep pox virion, and its potential use in sheep pox diagnosis via ELISA, has been reported by a number of authors [40,71]. Immunization of mice with VACV A4 protein, an ortholog of SPPV-095, induced a strong humoral immune response and ensured 50\% protection against a lethal dose (40 LD50) of VACV [57]. In contrast, our results revealed that although the recombinant SPPV-095 recombinant protein was antigenic in experimental rabbits, the antibodies produced to this protein failed to neutralize SPPV in kidney cell culture. The role of SPPV-095 protein in modulation of the immune system is still a matter of discussion.

\section{Conclusions}

In summary, antibodies raised to bacterially-produced SPPV-060, SPPV-117, and SPPV-122 proteins neutralized SPPV in cell culture, while antibodies to SPPV-095 protein did not possess virus-neutralizing activity. The findings of our studies show that bacterially-produced SPPV-060, SPPV-117, and SPPV-122 proteins may be used for development efficient strategies for prevention of infectious diseases caused by members of Capripoxvirus genus, family Poxviridae. In the future, the efficacy of novel recombinant vaccines based on a combination of these proteins will be evaluated in large animal studies for their ability to protect sheep against sheep pox virus.

Acknowledgments: The research was conducted under the International project ISTC \# K-1704 “Development of Methods to Construct Recombinant Prophylactic Means for Sheep Pox with use of Transgenic Plants." Mention of trade names or commercial products in this publication is solely for the purpose of providing specific information and does not imply recommendation or endorsement by the U.S. Department of Agriculture. USDA is an equal opportunity provider and employer.

Author Contributions: O.V.C., V.L.Z, L.G.N., and R.W.H. conceived and designed the experiments; O.V.C., B.K.I., E. T. T., V. M. S., K.T.S., etc. performed the experiments; K.K. and S.R. analyzed the data; S.W., T.A., C.B., R.C.D., F.B., C. M., K.R., and D.N. contributed reagents, materials, and analysis tools; O.V.C., V.L.Z., L.G.N., N.Y.K., and R.W.H. wrote the paper.

Conflicts of Interest: The authors declare no conflict of interest.

\section{References}

1. Carn, V. Control of capripoxvirus infections. Vaccine 1993, 11, 1275-1279. [CrossRef]

2. World Animal Health. Reports on the Animal Health Status and Disease Control Methods and Lists of Disease Outbreaks; Statistics O.I.E.: Paris, France, 1996.

3. Mangana-Vougiouka, O.; Markoulatos, P.; Koptopoulos, G.; Nomikou, K.; Bakandritsos, N.; Papadopoulos, P. Sheep poxvirus identification from clinical specimens by PCR, cell culture, immunofluorescence and agar gel immunoprecipitation assay. Mol. Cell. Probes 2000, 14, 305-310. [CrossRef] [PubMed]

4. The Center for Food Security and Public Health. 2008. Available online: http://www.cfsph.iastate.edu/ Factsheets/pdfs/sheep_and_goat_pox.pdf (accessed on 2 June 2016).

5. Babiuk, S.; Bowden, T.R.; Boyle, D.B.; Wallace, D.B.; Kitching, R.P. Capripoxviruses: An emerging worldwide threat to sheep, goats and cattle. Transbound. Emerg. Dis. 2008, 55, 263-272. [CrossRef] [PubMed]

6. Kitching, R.P.; Bhatt, P.P.; Black, D.N. The characterization of African strains of capripoxvirus. Epidemiol. Infect. 1989, 102, 335-343. [CrossRef] [PubMed]

7. Ivanyushchenkov, V.N.; Koreba, O.A.; Kekukh, V.G. Biological characterization of the sheep pox virus strain "NISKhI". Veterinariya 1990, 8, 22-24.

8. Kurchenko, F.P.; Ivanyushchenkov, V.N.; Ufimtsev, K.P.; Alekhin, A.F.; Gononov, Y.M.; Seytkasymov, B.K.; Kutumbetov, L.B.; Safonov, G.A.; Tatarintcev, N.T. Efficacy of the dried virus vaccine based on the sheep pox virus strain "NISKhI". Veterinariya 1991, 10, 21-23.

9. Yeruham, I.; Perl, S.; Nyska, A.; Abraham, A.; Davidson, M.; Haymovich, M.; Zamir, O.; Grinstein, H. Adverse reactions in cattle to a capripox vaccine. Vet. Rec. 1994, 135, 330-332. [CrossRef] [PubMed]

10. Beard, C.W.; Mason, P.W. Out on the farm with DNA vaccines. Nat. Biotechnol. 1998, 16, 1325-1328. [CrossRef] [PubMed] 
11. Ghendon, Y. Progress in development of viral polynucleotide (DNA) vaccines. Vopr. Virusol. 1999, 4, $148-154$.

12. Rao, T.V.; Bandyopadhyay, S.K. A comprehensive review of goat pox and sheep pox and their diagnosis. Anim. Health Res. Rev. 2000, 1, 127-136. [CrossRef] [PubMed]

13. Tkachyov, S.E.; Mitrofanova, E.E.; Maximova, T.G.; Bakhvalova, V.N.; Vlasov, V.V.; Morozova, O.V. Comparative analysis of the protective effect of DNA-vaccines with different genes of tick-borne encephalitis virus. Immunologiya 2000, 3, 26-29.

14. Lebedev, L.R.; Goncharova, E.P.; Sizov, A.A.; Bulychev, L.E.; Odegov, A.M.; Ryzhikov, A.B. Molecular constructs of experimental combined vaccines. Mol. Genet. Mikrobiol. Virusol. 2002, 1, 17-20.

15. Berhe, G.; Minet, C.; Le Goff, C.; Barrett, T.; Ngangnou, A.; Grillet, C.; Libeau, G.; Fleming, M.; Black, D.N.; Diallo, A. Development of a dual recombinant vaccine to protect small ruminants against peste-des-petits-ruminants virus and capripoxvirus infections. J. Virol. 2003, 77, 1571-1577. [CrossRef] [PubMed]

16. Zheng, M.; Jin, N.; Liu, Q.; Huo, A.; Li, Y.; Hu, B.; Ma, H.; Zhu, Z.; Cong, Y.; Li, X.; et al. Immunogenicity and protective efficacy of Semliki forest virus replicon-based DNA vaccines encoding goatpox virus structural proteins. Virology 2009, 391, 33-43. [CrossRef] [PubMed]

17. Pacchioni, S.M.; Bissa, M.; Zanotto, C.; Morghen, C.D.G.; Illiano, E.; Radaelli, A. L1R, A27L, A33R, and $\mathrm{B} 5 \mathrm{R}$ vaccinia virus genes expressed by fowlpox recombinants as putative novel orthopoxvirus vaccines. J. Transl. Med. 2013, 11, 95. [CrossRef] [PubMed]

18. Tulman, E.R.; Alfonso, C.L.; Lu, Z.; Zsak, L.; Sur, J.-H.; Sandybaev, N.T.; Kerembekova, U.Z.; Zaitsev, V.L.; Kutish, G.F.; Rock, D.L. The genomes of sheeppox and goatpox viruses. J. Virol. 2002, 76, 6054-6061. [CrossRef] [PubMed]

19. Betakova, T.W.; Wolffe, E.J.; Moss, B. The vaccinia virus A14.5L gene encodes a hydrophobic 53-amino-acid virion membrane protein that enhances virulence in mice and is conserved among vertebrate poxviruses. J. Virol. 2000, 7, 4085-4092. [CrossRef]

20. Chertov, O.; Telezhinskaya, I.N.; Zaitseva, E.V.; Golubeva, T.B.; Zinov'ev, V.V.; Ovechkina, L.G.; Mazkova, L.B.; Malygin, E.G. Amino acid sequence determination of vaccinia virus immunodominant protein p35 and identification of the gene. Biomed. Sci. 1991, 2, 151-154. [PubMed]

21. Franke, C.A.; Wilson, E.M.; Hruby, D.E. Use of a cell-free system to identify the vaccinia virus L1R gene product as the major late myristylated virion protein M25. J. Virol. 1990, 64, 5988-5996. [PubMed]

22. Niles, E.G.; Seto, J. Vaccinia virus gene D8 encodes a virion transmembrane protein. J. Virol. 1988, 62, 3772-3778. [PubMed]

23. Rodriguez, J.F.; Esteban, M. Mapping and nucleotide sequence of the vaccinia virus gene that encodes a 14-kilodalton fusion protein. J. Virol. 1987, 61, 3550-3554. [PubMed]

24. Salmons, T.; Kuhn, A.; Wylie, F.; Schleich, S.; Rodriguez, J.R.; Rodriguez, D.; Esteban, M.; Griffiths, G.; Locker, J.K. Vaccinia virus membrane proteins p8 and p16 are cotranslationally inserted into the rough endoplasmic reticulum and retained in the intermediate compartment. J. Virol. 1997, 71, 7404-7420. [PubMed]

25. Senkevich, T.G.; Weisberg, A.S.; Moss, B. Vaccinia virus E10R protein is associated with the membranes of intracellular mature virions and has a role in morphogenesis. Virology 2000, 278, 244-252. [CrossRef] [PubMed]

26. Takahashi, T.; Oie, M.; Ichihashi, Y. N-terminal amino acid sequences of vaccinia virus structural proteins. Virology 1994, 202, 844-852. [CrossRef] [PubMed]

27. Yeh, W.W.; Moss, B.; Wolffe, E.J. The vaccinia virus A9L gene encodes a membrane protein required for an early step in virion morphogenesis. J. Virol. 2000, 74, 9701-9711. [CrossRef] [PubMed]

28. Duncan, S.A.; Smith, G.L. Identification and characterization of an extracellular envelope glycoprotein affecting vaccinia virus egress. J. Virol. 1992, 66, 1610-1621. [PubMed]

29. Engelstad, M.; Smith, G.L. The vaccinia virus 42-kDa envelope protein is required for the envelopment and egress of extracellular virus and for virus virulence. Virology 1993, 194, 627-637. [CrossRef] [PubMed]

30. Hirt, P.; Hiller, G.; Wittek, R. Localization and fine structure of a vaccinia virus gene encoding an envelope antigen. J. Virol. 1986, 58, 757-764. [PubMed]

31. Isaacs, S.N.; Wolffe, E.J.; Payne, L.G.; Moss, B. Characterization of a vaccinia virus-encoded 42-kilodalton class I membrane glycoprotein component of the extracellular virus envelope. J. Virol. 1992, 66, 7217-7224. [PubMed] 
32. Roper, R.; Wolffe, E.J.; Weisberg, A.; Moss, B. The envelope protein encoded by the A33R gene is required for formation of actin-containing microvilli and efficient cell-to-cell spread of vaccinia virus. J. Virol. 1998, 72, 4192-4204. [PubMed]

33. Shida, H. Nucleotide sequence of the vaccinia virus hemagglutinin gene. Virology 1986, 150, 451-462. [CrossRef]

34. Moss, B. Poxvirus cell entry: How many proteins does it take? Viruses 2012, 4, 688-707. [CrossRef] [PubMed]

35. Malik, Y.P.S.; Chand, P. Detection and characterization of soluble proteins of sheep pox virus. Indian J. Anim. Sci. 2010, 80, 707-710.

36. Pandey, R.; Singh, I.P. Soluble antigens of sheep pox and goat pox viruses as determined by immunodiffusion in agar gel. Acta Virol. 1972, 16, 41-46. [PubMed]

37. Subba Rao, M.V.; Malik, B.S. Application of electroimmunodiffusion test for detection of antigenic relationship between sheeppox and goatpox viruses. Acta Virol. 1983, 27, 177-179. [PubMed]

38. Sambyal, D.S.; Singh, I.P. Immunogenicity of soluble antigens of sheep pox virus. Indian J. Anim. Sci. 1978, 48, 511-514.

39. Bhanot, V.; Balamurugan, V.; Bhanuprakash, V.; Venkatesan, G.; Sen, A.; Yadav, V.; Yogisharadhya, R.; Singh, R.K. Expression of P32 protein of goatpox virus in Pichia pastoris and its potential use as a diagnostic antigen in ELISA. J. Virol. Methods 2009, 162, 251-257. [CrossRef] [PubMed]

40. Bowden, T.C. Detection of antibodies specific for sheeppox and goatpox viruses using recombinant capripoxvirus antigens in an indirect enzyme-linked immunosorbent assay. J. Virol. Methods 2009, 161, 19-29. [CrossRef] [PubMed]

41. Carn, V.M.; Kitching, R.P.; Hammond, J.M.; Chand, P. Use of a recombinant antigen in an indirect ELISA for detecting bovine antibody to capripoxvirus. J. Virol. Methods 1994, 49, 285-294. [CrossRef]

42. Hein, H.G.; Stevens, M.P.; Foord, A.J.; Boyle, D.B. A capripoxvirus detection PCR and antibody ELISA based on the major antigen P32, the homolog of the vaccinia virus H3L gene. J. Immunol. Methods 1999, 227, 187-196. [CrossRef]

43. Krogh, A.; Larsson, B.; von Heijne, G.; Sonnhammer, E.L.L. Predicting transmembrane protein topology with a hidden Markov model: Application to complete genomes. J. Mol. Biol. 2001, 305, 567-580. [CrossRef] [PubMed]

44. Madden, T. The BLAST Sequence Analysis Tool. The NCBI Handbook [Internet], 2nd ed.; Bethesda (MD): National Center for Biotechnology Information (US), 2013. Available from: http:/ /www.ncbi.nlm.nih.gov/ books/NBK153387/ (accessed on 2 June 2016).

45. Ramirez, J.C.; Tapia, E.; Esteban, M. Administration to mice of a monoclonal antibody that neutralizes the intracellular mature virus form of vaccinia virus limits virus replication efficiently under prophylactic and therapeutic conditions. J. Gen. Virol. 2002, 83, 1059-1067. [CrossRef] [PubMed]

46. Rodriguez, J.F.; Smith, G.L. Inducible gene expression from vaccinia virus vectors. Virology 1990, 177, $239-250$. [CrossRef]

47. Hsiao, J.C.; Chung, C.S.; Chang, W. Vaccinia virus envelope D8L protein binds to cell surface chondroitin sulfate and mediates the adsorption of intracellular mature virions to cells. J. Virol. 1999, 73, 8750-8761. [PubMed]

48. Davies, D.H.; McCausland, M.M.; Valdez, C.; Huynh, D.; Hernandez, J.E.; Mu, Y.; Hirst, S.; Villarreal, L.; Felgner, P.L.; Crotty, S. Vaccinia virus H3L envelope protein is a major target of neutralizing antibodies in humans and elicits protection against lethal challenge in mice. J. Virol. 2005, 79, 11724-11733. [CrossRef] [PubMed]

49. Lin, C.L.; Chung, C.S.; Heine, H.G.; Chang, W. Vaccinia virus envelope H3L protein binds to cell surface heparin sulfate and is important for intracellular mature virion morphogenesis and virus infection in vitro and in vivo. J. Virol. 2000, 74, 3353-3365. [CrossRef] [PubMed]

50. Ichihashi, Y.; Oie, M. Neutralizing epitope on penetration protein of vaccinia virus. Virology 1996, 220, 491-494. [CrossRef] [PubMed]

51. Shinoda, K.; Wyatt, L.S.; Irvine, K.R.; Moss, B. Engineering the vaccinia virus L1 protein for increased neutralizing antibody response after DNA immunization. Virol. J. 2009, 6, 28. [CrossRef] [PubMed] 
52. Wolffe, E.J.; Vijaya, S.; Moss, B. A myristylated membrane protein encoded by the vaccinia virus L1R open reading frame is the target of potent neutralizing monoclonal antibodies. Virology 1995, 211, 53-63. [CrossRef] [PubMed]

53. Engelstad, M.; Howard, S.T.; Smith, G.L. A constitutively expressed vaccinia gene encodes a 42-kDa glycoprotein related to complement control factors that forms part of the extracellular virus envelope. Virology 1992, 188, 801-810. [CrossRef]

54. Law, M.; Smith, G.L. Antibody neutralization of the extracellular enveloped form of vaccinia virus. Virology 2001, 280, 132-142. [CrossRef] [PubMed]

55. Fogg, C.N.; Americo, J.L.; Lustig, S.; Huggins, J.W.; Smith, S.K.; Damon, I.; Resch, W.; Earl, P.L.; Klinman, D.M.; Moss, B. Adjuvant-enhanced antibody responses to recombinant proteins correlates with protection of mice and monkeys to orthopoxvirus challenges. Vaccine 2007, 25, 2787-2799. [CrossRef] [PubMed]

56. Hooper, J.W.; Custer, D.M.; Thompson, E. Four-gene-combination DNA vaccine protects mice against a lethal vaccinia virus challenge and elicits appropriate antibody responses in nonhuman primates. Virology 2003, 306, 181-195. [CrossRef]

57. Demkowicz, W.E.; Maa, J.S.; Esteban, M. Identification and characterization of vaccinia virus genes encoding proteins that are highly antigenic in animals and are immunodominant in vaccinated humans. J. Virol. 1992, 66, 386-398. [PubMed]

58. Madhaven, V.; Bhatt, F.; Jeffery, C.J. Recombinant expression screening of P. aeruginosa bacterial inner membrane proteins. BMC Biotechnol. 2010, 10, 83. [CrossRef] [PubMed]

59. Sahdev, S.; Khattar, S.K.; Saini, K.S. Production of active eukaryotic proteins through bacterial expression systems: A review of the existing biotechnology strategies. Mol. Cell. Biochem. 2008, 307, 249-264. [CrossRef] [PubMed]

60. Berhanu, A.; Wilson, R.L.; Kirkwood-Watts, D.L.; King, D.S.; Warren, T.K.; Lund, S.A.; Brown, L.L.; Krupkin, A.K.; VanderMay, E.; Weimers, W.; et al. Vaccination of BALB/c mice with Escherichia coli-expressed vaccinia virus proteins A27L, B5R, and D8L protects mice from lethal vaccinia virus challenge. J. Virol. 2008, 82, 3517-3529. [CrossRef] [PubMed]

61. Galmiche, M.C.; Goenaga, J.; Wittek, R.; Rindisbacher, L. Neutralizing and protective antibodies directed against vaccinia virus envelope antigens. Virology 1999, 254, 71-80. [CrossRef] [PubMed]

62. Rodriguez, J.F.; Paez, E.; Esteban, M. A 14,000-Mr envelope protein of vaccinia virus is involved in cell fusion and forms covalently linked trimers. J. Virol. 1987, 61, 395-404. [PubMed]

63. Lai, C.F.; Gong, S.C.; Esteban, M. The purified 14-kilodalton envelope protein of vaccinia virus produced in Escherichia coli induces virus immunity in animals. J. Virol. 1991, 65, 5631-5635. [PubMed]

64. Fogg, C.; Lustig, S.; Whitbeck, J.C.; Eisenberg, R.J.; Cohen, G.H.; Moss, B. Protective immunity to vaccinia virus induced by vaccination with multiple recombinant outer membrane proteins of intracellular and extracellular virions. J. Virol. 2004, 78, 10230-10237. [CrossRef] [PubMed]

65. Fogg, C.N.; Americo, J.L.; Earl, P.L.; Resch, W.; Aldaz-Carroll, L.; Eisenberg, R.J.; Cohen, G.H.; Moss, B. Disparity between levels of in vitro neutralization of vaccinia virus by antibody to the A27 protein and protection of mice against intranasal challenge. J. Virol. 2008, 82, 8022-8029. [CrossRef] [PubMed]

66. Lustig, S.; Fogg, C.; Whitbeck, J.C.; Eisenberg, R.J.; Cohen, G.H.; Moss, B. Combinations of polyclonal or monoclonal antibodies to proteins of the outer membranes of the two infectious forms of vaccinia virus protect mice against a lethal respiratory challenge. J. Virol. 2005, 79, 13454-13462. [CrossRef] [PubMed]

67. Gubser, C.; Hue, S.; Kellam, P.; Smith, G.L. Poxvirus genomes: A phylogenetic analysis. J. Gen. Virol. 2004, 85, 105-117. [CrossRef] [PubMed]

68. Earl, P.L.; Americo, J.L.; Wyatt, L.S.; Eller, L.A.; Whitbeck, J.C.; Cohen, G.H.; Eisenberg, R.J.; Hartmann, C.J.; Jackson, D.L.; Kulesh, D.A.; et al. Immunogenicity of a highly attenuated MVA smallpox vaccine and protection against monkeypox. Nature 2004, 428, 182-185. [CrossRef] [PubMed]

69. Subba Rao, M.V.; Malik, B.S.; Sharma, S.N. Antigenic relationships among sheep pox, goat pox and contagious pustular dermatitis viruses. Acta Virol. 1984, 28, 380-387. [PubMed] 
70. Dashprakash, M.; Venkatesan, G.; Ramakrishnan, M.A.; Muthuchelvan, D.; Sankar, M.; Pandy, A.B.; Mondal, B. Genetic diversity of fusion gene (ORF 117), an analogue of vaccinia virus A27L gene of carpipox virus isolates. Virus Genes 2015, 50, 325-328. [CrossRef] [PubMed]

71. Orlova, E.S. Improving Methods of Sheep Pox and Goat Pox Diagnosis. Ph.D. Thesis (Biol.Sci.), Federal Centre for Animal Health (FGBI “ARRIAH”), Vladimir, Russia, 2007. 